\title{
Effect of Price, Promotion, and Facilities to Customer Satisfaction in Using the Service Event Management
}

\author{
Ratih Puspitaningtyas Faeni, Dewi Puspaningtyas Faeni
}

\begin{abstract}
This study aimed to observe how Price, Promotion and Facility can affect customer satisfaction and to analyze the influence of these three variables on customer satisfaction in using Event Services Organizer MCI Management. This research was conducted by questionnaire method to 80 respondents of MCI Management Event Organizer participants and obtained by using simple random sampling technique analyzed in the form of quantitative and qualitative analysis. The result of this study shows that the three independent variables tested have positive and significant effect on customer satisfaction through $F$ test with sig $<0,05$ and t test value, $<0,05$ while Adjusted $R$ Square number 0,919 shows $91,9 \%$ variation of Satisfaction Customers that can be explained by the three independent variables, where the remaining $8.1 \%$ can be explained by other factors outside this study.
\end{abstract}

\section{INTRODUCTION}

\section{A. Research Background}

The growing business world, the business competition is getting bigger. For that every company is required to continue to keep perfomanya business world in order to still exist. A good company is a company that quickly and precisely make decisions when looking at opportunities. Business activities that are growing in the community are Event Organizer (EO) as a strategy to promote products, accelerate sales, increase sales figures and build corporate image [1-5].

Every company needs event organizer to support marketing. Good product launching, seminars, workshops or other special events needed the role of event organizer in the implementation, so that every event can be done later based on one of the strategies to win the competition in this globalization is to implement the concept of constumer satisfication. Customer satisfaction event can be realized what if the company is able to meet customer needs and desires at least the same as the expected customer event. Event customer satisfaction is very important for the company because customer satisfaction determines the income that will be obtained by the company. Customer satisfaction is a function

Revised Manuscript Received on July 05, 2019.

Ratih Puspitaningtyas Faeni,

Faculty of Economics and Business, Universitas Budi Luhur, ratih.puspitaningtyas@budiluhur.ac.id of close proximity between buyers' expectations of the product [6-10].

Customer satisfaction can be realized because of the professional performance in the event organizer by fulfilling all the requests that customers want. If this can be realized, it can be in the customer will be satisfied [11-14].

Adequate facilities are some of the criteria that the customer will consider. The completeness of the event facility will be very helpful in maintaining the customer, the facility is not only equipment that can support the convenience of customers but while in the event area, but everything that makes customers feel to find the services of a permanent event organizer to feel a satisfaction from the event [15].

In the process of making customer satisfaction must solve the problem in the perceived needs and keinginanya to meet the needs with the consumption of products or services accordingly.

Facilities can facilitate customers to perform an activity. Customers are very critical and careful about using the money. They consider many factors to choose a product or service event organizer including facilities that become one of the customer's considerations in making choices. The more complete facilities owned by the customer company are increasingly interested in choosing the product or service event organizer offered by a company [16-17].

So can be predicted, the next competition is not only competition on price, but also on other variables of promotion. Due to the increasing desire of customers, then in taking customer satisfaction will be different - different in the success of an event organizer service company [18].

Promotions must be creative and as attractive as possible in order to attract customers. The promotion presented should have an interesting theme, a good image that has a high selling value and in accordance with the event that we offer that will ultimately affect customer satisfaction [19].

Basically satisfaction of a product or service will affect the pattern of subsequent behavior. If the customer feels fasting, then he will show the magnitude of the possibility to re-use the services of the same event organizer. Satisfied

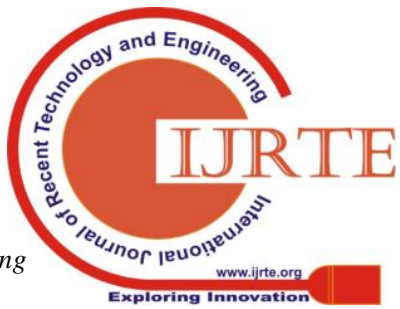


customers will also tend to give good references to others. Not so with dissatisfied customers. The customer will prefer to seek information about the event organizer services. Then they prefer to service event organizers who are considered able to meet the satisfaction of their wishes and leave the services of the previous event organizer. And these customers will not recommend the event organizer services that he deems incapable of meeting customer satisfaction [20].

\section{B. Problem Identification}

1. Does the price partially affect customer satisfaction in MCI Management, Jakarta?

2. Does partial promotion affect customer satisfaction in MCI Management, Jakarta?

3. Does the facility partially affect customer satisfaction in MCI Management, Jakarta?

4. Are prices, promotions, and facilities simultaneously affecting customer satisfaction at MCI Management, Jakarta?

C. Research Purpose

1. To determine the effect of price partially on customer satisfaction

2. To find out the promotion partially to customer satisfaction

3. To know the diversity of facilities partially to customer satisfaction simultaneously to customer satisfaction

D. Hypothesis

1. Hypothesis testing partially between price (X1) to customer satisfaction (Y)

2. Ha: There is a partial price effect on customer satisfaction.

3. Hypothesis testing partially between promotion (X2) to customer satisfaction (Y).

4. Ha: There is a partial promotion effect on customer satisfaction.

5. Hypothesis Testing partially between facilities (X3) to customer satisfaction ( $\mathrm{Y}$ ).

6. Ha: There is partial influence of the facility on customer satisfaction.

7. Simultaneous testing hypothesis between price (X1), promotion (X2), facility (X3) to customer satisfaction (Y)

8. Ha: There is influence of price, promotion, facility simultaneously to customer satisfaction

II. LITERATURE REVIEW

\section{A. Price}

Price is the amount of money that is billed for a product or service, the amount of value that consumers exchange for the benefit of owning or using a product or service. "Price is the only element of the marketing mix that provides income or income for the company, while the other three elements (product, place, and promotion) lead to cost / expense" (Fandy
4. To know the influence of price, promotion, and facility Tjiptono, 2008: 151). (Kotler, 2005).

Price is the amount of money the customer must pay to get the product ". Besides, the price is a marketing mix element that is flexible, meaning it can be changed quickly. The usual price is expressed by various terms, such as tuition, tariff, rental, interest, premium, commission, salary, wage, honorarium, SPP, the view of marketing, the price is the monetary unit or other measure (including other goods and services) exchanged in order to obtain the right of ownership or use of a good or service. Meanwhile, from the consumer's point of view, the price is often used as an indicator of value when the price is linked to benefits perceived on a good or service (Kotler and Armstrong, 2008)

\section{B. Promotion}

Promotion is one element in the marketing mix of companies that are used to inform, persuade, and remind about the company's productson the above understanding of promotion can be concluded that the promotion it is a kind of communication that provides a convincing explanation to potential customers about goods or services. Promotions are used to tell people information about a product and persuade a buyer or target market to be able to buy the product on offer (Stanton and Saladin, 2006).

\section{Facilities}

Facility is a means to facilitate and facilitate the execution of functions. Facility is an individual component of offering that is easily added or reduced without changing the quality and model services. Facilities are also a tool to differentiate one organizer one of the other competitors (Rambat Lupiyoadi \& Ahmad Hamdani, 2008: 150). From the above theory the authors draw a conclusion that the facility is one of the factors that affect customer satisfaction.

Facility is a means to facilitate and facilitate the execution of the function. Facility is an individual component of the offer that is easily added or reduced without menguah quality or service model. Facility is also a tool to distinguish one educational institution programs from other competitors. Working facilities are a means of support in the form of physical activities of the company, and used in the normal activities of the company, has a period of permanent relativ usefulness and provide benefits for the future. Working facilities are very important for the company, because it can support the performance of employees, such as in the completion of work, facilities as a means of support to create work motivation on employee performance such as :

1. Things that need to be delivered in service facilities among others.

2. completeness of hygiene and tidiness of the facilities offered.

3. Condition and function of the facilities offered.

4. Ease of use of the facilities offered.

5. Completeness of tools offered.

\section{Customer Satisfaction}

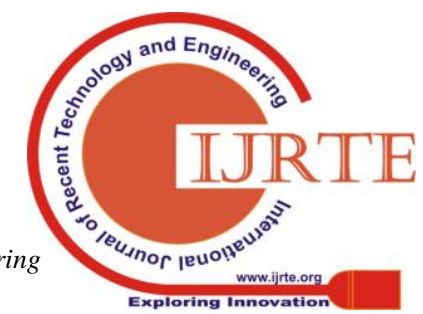


Customer satisfaction is a long-known concept in marketing theory and application, customer satisfaction being one of the essential objectives for business activity, seen as one of the best indicators to achieve future profit, triggering efforts to increase customer satisfaction.

Customer Satisfaction According to Ali Hasan (2014: 89): "Satisfaction or dissatisfaction as a purnabeli evaluation where perceptions of the performance of selected products meet or exceed expectations before purchase. If the perception of performance can not meet expectations, then what happens is dissatisfaction. "According Handi Irawan (2007: 2): Customer satisfaction is the result of accumulation of consumers or customers in using products or services. According to Handi Irawan (2007: 37-40).

\section{E. Research Framework}

Framework of thinking is a synthesis of relationships between variables compiled from various theories that have been described. Another opinion, according to Riduwan (2008: 25 ), the frame of thought or frame of thought is the rationale of the research synthesized from the facts, observations and has been the literature. Therefore, the frame of thinking contains theoritical theories or concepts that will be used as a basis in research (Sugiyono, 2011).

\section{Source : Primary Data}

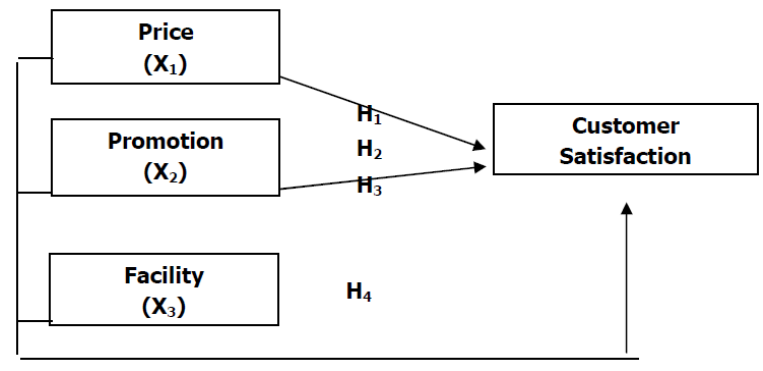

Figure 2. Research Framework

\section{RESEARCH METHODOLOGY}

\section{A. Research Object}

In this study the population is the participants using the service event organizer in MCI Management. Based on the sources obtained, the participants who use event organizer services ranges from 100 people to the population of each event will be found the number of samples that will be made as respondents are as many as 80 respondents. Quantitative research type, the sample in this research is the participant who use event organizer service in MCI Management. The research method using probability sampling method is Simple Random sampling. The analysis conducted for data processing of this research with statistical approach. Analytical techniques use Validity test, reliability test, multiple linear regression, $t$ test and $F$ test with SPSS 20 For Windows tool. Instrument measurement instrument used there are 4 kinds namely: Price, Promotion, Facility and customer satisfaction. Price Scale is divided into 3 aspects such as: product, Cost Oriented Pricing, Demand Oriented Princing, Competetion Oriented Pricing (Tjiptono, 2008).Collecting data is done by way of direct to the research object such as .

\section{1) Interview}

The authors conducted direct interviews with company leaders and a number of research-related employees to look for strengths, weaknesses and opportunities of MCI Management.

\section{2) Questionnaire}

Penuli distributes questionnaires to participants to get live data from more accurate participants.

\section{3) Observation}

A form of research conducted by the author by observing the operational activities and performance of MCI Management.

4) Documentation

Documents relating to this research are collected

\section{RESULTS AND DISCUSSIONS}

A. Classic Assumption Test

1) Nomrmality Tests

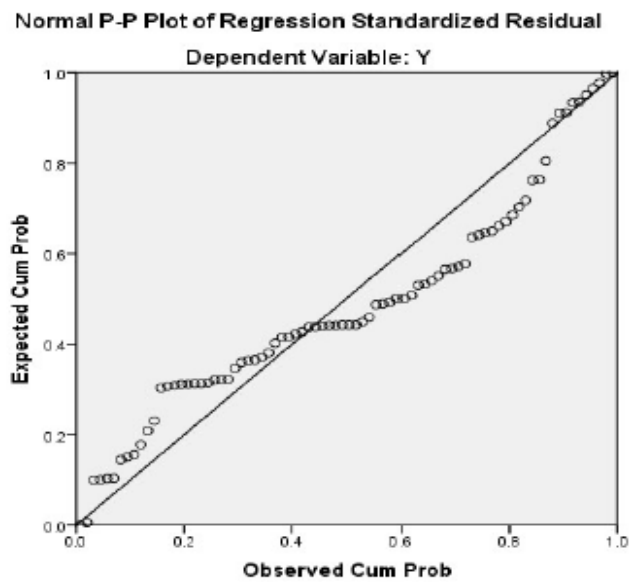

Figure 4. Normality Test

2) Multicolinearity Test

Tabel 4 :Colinearity

\begin{tabular}{|l|l|l|}
\hline \multirow{2}{*}{ Model } & \multicolumn{2}{l|}{ Collinearity Statistics } \\
\cline { 3 - 4 } & Tolerance & $\mathrm{VIF}$ \\
\hline 1 & (Constant) & \\
\hline
\end{tabular}




\begin{tabular}{|l|l|l|l|}
\hline Price X1 & 0,243 & 4,117 \\
\cline { 2 - 4 } & Promotion X2 & 0,480 & 2,084 \\
\hline Facility X3 & 0,198 & 5,059 \\
\hline
\end{tabular}

Test Results Variance Inflation Factor (VIF) and Tolerance

Source: SPSS 20.0, 2017.

In the above output results (Table 4.17), each independent variable has:

$$
\begin{aligned}
& \begin{array}{l}
\text { a. }\left(\mathrm{X}_{1}\right) \cdot \text { Tolerance }: 0,243>0,1 \\
\text { - VIF } \quad: 4,117<10 \\
\text { b. }\left(\mathrm{X}_{2}\right) \cdot \text { Tolerance }: 0,480>0,1 \\
\text { - VIF } \quad: 2,084<10 \\
\text { c. }(\mathrm{X} 3) \cdot \text { Tolerance }: 0,198>0,1 \\
\text { - VIF } \quad: 5,059<10 \\
\text { 3) Heteroscedasticity Test }
\end{array}
\end{aligned}
$$

\begin{tabular}{|c|c|c|c|c|c|c|}
\hline & & $\begin{array}{l}\text { Unsta } \\
\text { Coef }\end{array}$ & $\begin{array}{l}\text { ardized } \\
\text { nts }\end{array}$ & $\begin{array}{l}\text { Standardi } \\
\text { zed } \\
\text { Coefficie } \\
\text { nts }\end{array}$ & $\mathrm{T}$ & Sig. \\
\hline & & B & $\begin{array}{l}\text { Std. } \\
\text { Error }\end{array}$ & Beta & & \\
\hline 1 & (Constant) & .342 & .497 & & 689 & .493 \\
\hline & $\mathrm{X} 1$ & .630 & .062 & .662 & 10.195 & .000 \\
\hline & $\mathrm{X} 2$ & .168 & .056 & .138 & 2.990 & .004 \\
\hline & X3 & .185 & .060 & .221 & 3.074 & .003 \\
\hline
\end{tabular}

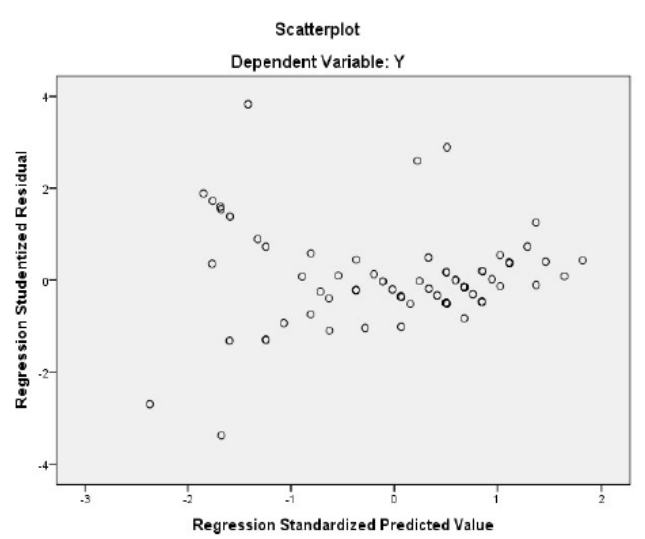

Multilinear Regression

Table 4 :Multilinear Regression

4)

\section{Hypothesis Test}

t-Tests

Regression test regression for price variable X1 significance value is less than <0.05 Regression test regression for promotional variable $\mathrm{X} 2$ significance value is less than $<0.05$ Statement of regression test for facility X3 variable of significance value is less than $<0.05$.

\section{f-Tests}

\begin{tabular}{|l|l|l|l|l|}
\hline Model & $\mathrm{R}$ & $\begin{array}{l}\mathrm{R} \\
\text { Square }\end{array}$ & $\begin{array}{l}\text { Adjusted R } \\
\text { Square }\end{array}$ & $\begin{array}{l}\text { Std. Error of } \\
\text { the Estimate }\end{array}$ \\
\hline 1 & $.960^{\mathrm{a}}$ & .922 & 0,919 & .89275 \\
\hline
\end{tabular}

Description: that the $\mathrm{F}$ test shows a significance value less than $<0.05$

Coefficient Determination

\section{CONClusion AND Suggestions}

\section{A. Conclusions}

1. Price (X1) partially has a significant positive effect on customer satisfaction (Y) in Event Organizer MCI Management.

2. Promotion (X2) partially has a significant positive effect, on customer satisfaction (Y) in Event Organizer MCI Management.

3. Facility (X3) has a positive and significant influence on customer satisfaction (Y) in Event Organizer MCI Management

4. Price, Promotion and Facilities can simultaneously affect customer satisfaction using Event Organizer MCI Management service

\section{B. Suggestions}

With regard to the results of the analysis and discussion in the previous chapter, the author's suggestion to be given to MCI Management Event Organizer in relation to Price, Promotion and Facilities Effect on Customer Satisfaction using Event Organizer MCI Management services are as follows:

1. MCI Management Event Organizer should pay more attention to or multiply places or spots for participants to make purchasing decisions.

2. The addition of promotional media and the addition of warehouses to the participants should be more rethought.

3. Special pricing for loyal participants using MCI Management Event Organizer services in sales promotion

4. For Event Organizer Management MCI Management must continuously improve the quality of service and maintain good communication to the participants In order to participants feel satisfied using Event Organizer MCI Management.

Ethical clearance - Not required

Source of funding- Self

Conflict of Interest - Nil

Published By:

Blue Eyes Intelligence Engineering 


\section{References}

[1] Ahmad Subagyo. Marketing In Business. Jakarta: Mitra Wacana Media, 2010.

[2] Ali Hasan. Marketing. yogyakarta: Media Utama, 2008.

[3] Ali Hasan. Marketing dan Kasus-Kasus Pilihan. Cetakan Kedua. yogyakarta: CAPS, 2014.

[4] Handi Irawan. Sepuluh Perinsip Kepuasan Pelanggan. Cetakan Kesembilan. Jakarta: PT Elex Media Komputindo, 2007.

[5] Djaslim Saladin. Manajemen Pemasaran Analisis, Perencanaan, Pelaksanaan dan Pengendalian, Bandung: CV. Linda Karya, 2008.

[6] Durianto. Strategi Menaklukan Pasar. Jakarta: Gramedia Pustaka, 2004

[7] Fandy Tjiptono. Manajemen Jasa edisi 2.Yogyakarta: CV. Andi., 2002.

[8] Fandy Tjiptono. Strategi Pemasaran. Edisi ketiga. Yogyakarta: CV Andi OFFSET, 2008.

[9] Fandy Tjiptono dan Gregorius Candra. Pemasaran Strategik. Yogyakarta: Andi, 2012.

[10] Gitosudarmo Indriyo. Manajemen Pemasaran. edisi pertama. cetakan keempat. Yogyakarta: BPFE, 2008..

[11] Husein Umar. Metode Penelitian untuk Skripsi dan Tesis Bisnis. Jakarta: Gramedia Pustaka Utama, 2008.

[12] Imam Ghozali. Aplikasi Analisis Multivariat Dengan Program SPSS, Cetakan Keempat. Badan, Penerbit Universitas Diponegoro, Semarang, 2006.

[13] Kotler, Philip. Manajemen Pemasaran. Jilid 1. Jakarta: PT. Indeks Kelompok Gramedia, 2005. 